\title{
The Translation Process of Projection from Batak Toba Language into English
}

\author{
Sanggam Siahaan ${ }^{1}$, Tengku Silvana Sinar $^{2}$ \\ ${ }^{1}$ Universitas HKBP Nommensen, Pematangsiantar, Indonesia, ${ }^{2}$ Universitas Sumatera Utara, Medan, Indonesia
}

\begin{abstract}
This article is about the projection translation process from the Batak Toba language into English. The main problem explored is the application of heuristic translation strategy to achieve the functional equivalence. The strategy depends on the systemic functional grammar theories which is considered as the power house of the meaning creation of language and the bottom-up approach for the meaning analysis when two grammatical aspects go up to a higher level in a text. The research is subject to three concurrent activities in the transfer process of projection samples quoted from the transcription of the Batak Toba traditional wedding speeches as the source text into English as the target text. The findings indicate that heuristic translation strategy can meaningfully transfer all of the projection samples from the source text into the target text.
\end{abstract}

Keywords: Batak Toba traditional wedding speech, bottom-up approach, functional equivalence, heuristic translation strategy, systemic functional grammar, projection.

\section{Introduction}

This study is about an exploration on the decision of functional equivalence which is used as the parameter to determine the translation quality of projection, a type of the logical functions, existed in the traditional wedding speeches (henceforth as TWS) of the Batak Toba people (henceforth as BTP), a sub-tribe of the Batak people who mainly settle around the coast of Lake Toba, such as the District of Toba Samosir, the district of Samosir, the district of Humbang Hasundutan, and the district of Tapanuli Utara, in the Province of North Sumatera, Indonesia, as the source text (henceforth as ST) in the Batak Toba language (henceforth as BTL) as the source language (henceforth as SL) into the target text (henceforth TT) in English as the target language (henceforth as TL).

Delivering a spontanious speech in a wedding party is a compulsory spoken tradition in the Batak Toba society. Its history refers to their ancestor's maxim as in "Ompunta sijolo-jolo tubu martungkot si ala gundi, napinungka ni ompunta na parjolo siihuttonnon ni naparpudi." which means that the tradition of the former generation must be maintained by the following one (Siahaan, 2012: 4). With this local wisdom, the BTP extend their ideology, proposition, and proposal about the strong long term house hold harmony of a new family and their entire relatives as a whole. It is their ideology that of spring, wealthy, power, dignity, health, and long life as extended in the wedding speech will become a reality provided they are all subject to the house hold mores (Simanjuntak, 2005: 142; Sihombing, 1989; and Hutagalung, 1991). As a fact, no scientific work appears in the literature which provides this local wisdom information for the spreading up BTP generation both in their origin and in the diasporas, consequently the translation of this ST into the TT is considered as a wise decision to provide a document which can function as a reference for the new generation of the BTP wherever they settle, and in addition it will also serve as a cultural information exchange media among the international societies. Despite of that central function as a sociocultural behavior control, a wedding speech of the BTP contains numerous complex patterns of logical functions as the root of difficulties in the translation process of this text into the TT. The problem evolves is that there must be a stable and reliable translation strategy to provide a scientific account on how such complex patterns of logical meanings go into the process of translation from the Batak Toba language into English and why the execution of the process can be done meaningfully.

For the sake of the visibility of the research reported in this article, two concurrent preliminary studies are conducted. First, 15 wedding speeches from a wedding party place are video camera recorded, transcribed to become a ST, and based on SFG theory. The analysis shows that this ST contains 240 clauses which can beclassified into 98 clause simples and 142 clause complexes. Within the 142 clause complexes, there are 254 clause simples which create the types of the logico-semantic relations into 21 elaborations, 47 enhancements, 15 extensions, 33 projections which are classified into 17 locutions and 16 ideas, and 26 complex patterns of elaboration, extension, enhancement and locution head. Second, a translation process try out on the projections indicates that it needs a strategy which can explain the transfer of these specific meaning from the ST into the TT. The question arises is what strategy seemingly provides a scientific account how these functions from the ST can be transferred into the TT. A promising one which provides this scientific account must come from a 
conscious translation execution experience which is called as heuristic translation strategy. It is heuristic, because it is constructed based on the experience in assessing the problem encountered in the preliminary study for the sake of this real research. The objective of this article is to demonstrate how this strategy is applied to assess a specific projection type in the ST, how it is picked up and kept in the mind of a translator, how it is transferred into the TT by selecting the lexico-grammatical aspect to replace the lexico-grammatical aspect from the TL to replace the equivalent logical function in the TT, and how the translation quality is conducted to determine the relation between the ST and TT.

\subsection{Translation Theory}

\section{Related Literature}

Translation is a process of transferring the meanings of the ST into an equivalent TT (Bell, 1991:13; Manfredi, 2008:21). It involves some stages for the acquisition of the logical meanings of the ST and their transfer into the TT. It refers to translation as a product of the process of translation (Bell, 1991:13; Halliday, 1992:15; Manfredi, 2008:21). It refers to a translation which serves as TT. It has the function which is the same as the function of the ST (Catford, 1965:20; House, 2001:247). This means that translation can be specifically defined as a process of transferring meaning such as the logical meaning of a ST into a TT.

\subsection{Translation Equivalence}

Equivalence is a text which is some sort of reproduction of another text, originally written in another language (House 2001: 247). It is also defined as a concept used to explain the nature and extent of the relationship which exists between the ST and TT (Shuttleworth \& Cowie, 1997:49). It is said that equivalence is the relationship between the ST and TT. Kenny in Baker (1998:77) says that it is the relationship which allows the TT to be considered as a translation of the ST, however it is also said that full equivalence on code unit between the ST and TT can never be achieved (ibid. 36). Nida and Taber (1969:12) says that translating consists in reproducing in the receptor language the closest natural equivalence of the SL message, the first in term of meaning and secondly in term of style. It implies that the nature and extent of equivalence between the ST and TT refers to the meaning and style. Catford (1965:21) says that the central problem of translation practice is that finding TL translation equivalence. Manfredi (2008) defines it based on function which refers to the same function of the lexico-grammatical features of the ST which are replaced into the lexico-grammatical features of the TT. Halliday (2001:15) says that functional equivalence can be classified into stratification, metafunction, and rank. Manfredi (2008) says that a clause simple as a lexico-grammatical feature of a lower rank works to makes its logical function or meaning when it enters together with the other equal rank of lexico-grammatical feature into a clause complex in a text. The concept of functional equivalence can be specified to refer to the nature and extent of the logical meaning which is created by a clause simple when it enters with the other clause simple of the same rank into a clause complex of a higher rank in between the ST and TT.

\subsection{Translation Strategy}

Krings (1986:18) defines translation strategy as a potential conscious plan of a translator in solving the factual translation problem in the framework of a concrete translation task. The focus of a strategy in this definition deals with three main things, they are: conscious plan, concrete translation task, and translation problem solution. Loescher (1991:8) defines translation strategy as a potential conscious procedure for solving a problem faced in translating a text, or any segment of it. Cohen (1998:4) says that the elements of consciousness are what distinguish strategies from the processes which are not strategic. Jaaskelainen (1999:71) says that strategy is a series of competencies, a set of steps or processes that favor the acquisition, storage, and/or utilization of information; and also says that strategies are "heuristic and flexible in nature, and their adoption implies a decision influenced by amendments in the translator's objectives. This implies that a translator's strategy must contain a set of competencies which involves the process of acquiring information from the ST, storing them in the mind of the translator, and utilizing it into the TL. The strategy which is heuristic and flexible meant here can refer to the real fact such as the unique nature of the text which is different from the other text experienced by the translator. So this implies that the translator himself is suggested to develop his own strategy which fits to the amendments of his own objective. Jaaskelainen (2005) divides strategies into two major categories: some strategies relate to what happens to texts, while other strategies relate to what happens in the process. This implies that translation is divided into translation as a product and as a process. The strategy which relates to the product refers to handle with what happens in both the ST and the TT. The one which relates to the process refers to handle with what must happen in the process. Although, both the strategies for the product and the process are related, but the one for what happens in both the ST and TT is different from what must happen in the process. 


\subsection{Bottom-up Translation Approach}

The term Bottom-up Approach meant here refers to the concept of translation strategy in which its operation is basically based what happen in both the ST and TT and what must happen and translation process. Manfredi (2008:38) says that a text meaning analysis is based on the relation of context and language. It is said that an analysis focusing on how language embedded in context can prove itself to be a real help in the act of translating. This approach suggests that the act of translating departs from the analysis of the lexico-grammatical realization to the identification of meanings it realizes in a text and to reconstruct the context which activates such meanings and wording. Then the translator will be able to translate it accordingly, taking into account both the source and the target context. It is suggested that the analysis must departs from the general meaning of a text around the text, which is called "co-text", to the precise and specific one in a real wider context. Torsello (1996: 88) says that grammar should be a part of the education of a translator, and in particular grammar since it is concerned with language in text and with the role grammar plays, in combination with lexicon, in carrying out specific function and realizing specific type of meaning. So it is clear that bottom-up approach mean here is the basic component of a translation strategy in which the translator views how language works to make meaning based on the SFG theories as a part of SFL. By this approach a translator begins his or her activity in the process of translating from the analysis on how the lexico-grammatical aspects creates meaning in their context in the ST, and from there the translator tries the probability of replacing the lexico-grammatical aspect into the TT for the ST to realize the equivalent meaning. To do the validation of the translation process on the translated text as a product, the translator will work on the analysis of the TT to prove its equivalence to the ST. The Analysis of the equivalence must be done based on the concept of the bottom-up strategy i.e. to check the relation between ST and TT per lexico-grammatical aspect and per function of that lexico-grammatical aspect. A match per aspect means that there is equivalence between the ST and TT in that domain and extent.

\subsection{Projection}

Projection is a type of logico-semantic relation which is realized by clause complexes. Halliday (1994) views clause complexes based on two approaches. First is by the tactic system which are divided into the paratactic and hypotactic. Paratactic is a system in which each of the clauses in a clause complex is independent to each other. Each of them is symbolized by number. If this system has two clauses, the first one is symbolized by number 1 and the second one is symbolized by number 2. For instance "Mary has some friend; Susan is one of them" is a paratactic with two independent clauses. Here it is symbolized by 12 as in " 1 Mary has some friends; 2 Susan is one of them". If the system has more than two clauses such as "Mary has two friends; her first friend is Susan; the second is Jill", it is symbolized by 123 as in " 1 Mary has two friends; 2 her first friend is Susan; 3 the second is Jill. The hypotactic system is the one with clauses of interdepency relation. An independent clause is symbolized by $\alpha$ while a dependent one which is not necessarily embedded in the independent one is symbolized by $\beta$. Another dependent clause within $\beta$, but which is not necessarily embedded in it is symbolized by $\gamma$. The other dependent clause within $\gamma$, but which is not necessarily embedded in it, is symbolized by $\delta$. The continuation of the first clause up to the last one is symbolized by $\alpha \beta \gamma \delta$. For instance each of the clauses in a clause complex such as "Mary who loves john the young man who works in my father's company which its head quarter is in this city is my sister." is symbolized as in " $\alpha$ Mary is my sister; $\beta$ who loves john the young man; $\gamma$ who works in my father's company; $\delta$ which its head quarter is in this city." In a real text i.e. spoken and written text, the stretches of the clauses in clause complexes such as in the example above create a block of meanings in which the structure or pattern of logical functions or meanings can be analyzed.

The second approach is by the logico-semantic relation i.e. the logical function created by a clause in either a paratactic relation or a hypotactic one. Halliday (1994) classifies logical function into expansion and projection. Projections are classified into locution and idea. Locution is differentiated from an idea based on the process used in their projecting clause. Locution refers to the function of a clause to be projected by a projecting clause through wording the projected clause. A locution is projected by a projecting clause with a verbal process. Idea refers to the function of a projected clause to be projected by a projecting clause through the meaning of the projected clause. An idea is projected by a projecting clause with a mental process.

\subsection{The Research Design}

\section{RESEARCH METHOD}

This study is categorized as a qualitative design with multiple realities as the research problems to be investigated. The main topic of the problems explored is focused on the application of heuristic translation strategy which concerns with a translation strategy involving some stages which contains conscious knowledge on the application of the BTA and SFG theories in transferring some patterns of the projection types such as locution, idea, proposition idea and proposal idea from the ST into TT. The research design which represents the 
data collection of the ST, the logico-semantic relation analysis of the ST and transfer of the logico-semantic relation into the TT together with its translation quality assessment is as in Fig.1.

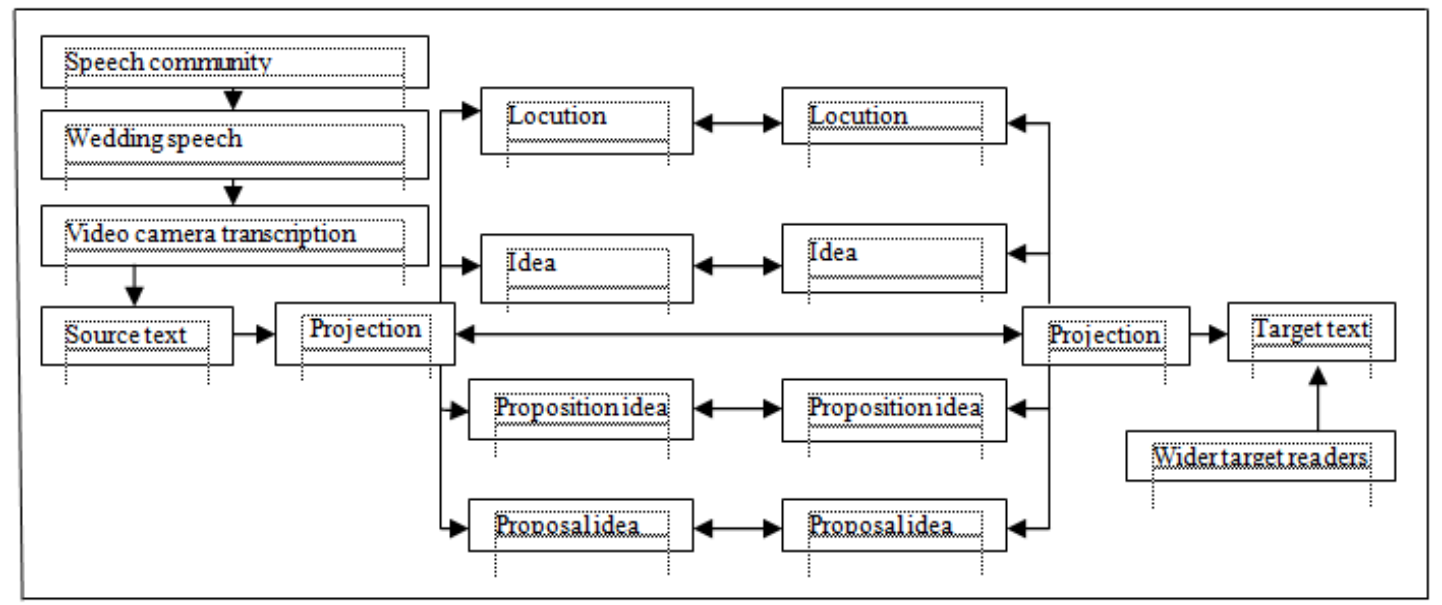

Figure 1 The Research Design

\subsection{Research Subject and Object}

The research subject of this study is the TBP participating a wedding speech genre of a traditional wedding party of the BTP in Balige, North Sumatera, Indonesia. The object of the study is focused on the translation process of projection of the ST into TT. The projection, a type of the logical functions, such as locution, idea, proposition idea, and proposal idea, existed in the ST containing some wedding speeches which are recorded with a video camera from TWP of the BTP held in Balige, North Sumatera, Indonesia.

\subsection{Translation Procedure}

The translation procedure conducted in this research has some stages as follows.

Stage 1: ST analysis

Stage 2: ST Projection analysis

Stage 3: Projection transfer

Stage 4: TT Projection analysis

Stage 5: TQA

The ST analysis in stage 1 is conducted to break the ST into clauses which are categorized into clause simple and clause complexes. The analytical framework used in the clause separation is based on the transitivity system saying that one experience is represented by one clause simple containing one process plus at least one participant and one circumstance, and based on the tactic system saying that one clause complex at least contain two clause simples having internal relationship. One of the clauses can be independent or dependent in relation to the other one. If the two clauses are independent to each other, the clause complex is called as the paratactic clause complex, but if one of them is independent and the other one is dependent, the clause complex is called hypotactic clause complex.

The ST projection analysis in stage 2 is conducted to determine the projection into their categories such as locution, idea, proposition idea, and proposal idea. The analytical framework used in this stage is based on the logico-semantic relation of the clauses in the clause complexes.

The Projection transfer in stage 3 is conducted to pick up the projection from ST and keep it in the mind of the translator, then to select the equivalent lexico-grammatical feature oF the TL to replace the lexico-grammatical features of the SL to realize the projection in the TT.

The TT projection analysis in stage 4 is conducted to determine the projection into their categories such as locution, idea, proposition idea, and proposal idea. The analytical framework used in this stage is based on the logico-semantic relation of the clauses in the clause complexes.

The Translation quality assessment in stage 5 is conducted to assess the translation quality. It is to determine the quality of the relation between the ST and TT. The analytical framework used in this stage is based the functional equivalence concept saying that a good translation is the one if a specific lexicogrammatical aspect from the lower level up to the higher level of the ST has the same function with the function of a specific lexico-grammatical aspect from the lower level up to the higher level in the TT.

The five stages in the translation procedure discussed above is summarized as in the translation process of the locution ninna lae, "boanon ku do $i$ tu adat from the ST into a functional equivalent locution my brother- 
in-law says, "I will bring the cloth to a traditional party." The summary of the stages is concretely illustrated as in the following table.

Projecting clause:

ninna lae

Table 1 Example of Translating Locution 1

\begin{tabular}{|l|l|l|}
\hline LSR & \multicolumn{2}{|l|}{ projecting clause } \\
\hline ST & ninna lae \\
\hline Lexis & ninna & lae \\
\hline TS & process: verbal & sayer \\
\hline Lexis & says & brother-in-law \\
\hline TT & brother-in-law says \\
\hline LSR & projecting clause \\
\hline
\end{tabular}

Projected clause:

Boanon ku do i tu adat

Table 2 Example of Translating Locution 2

\begin{tabular}{|l|l|l|l|l|l|l|l|}
\hline LSR & \multicolumn{6}{|l|}{ projected clause } \\
\hline ST & boanon ku do i tu ulaon adat \\
\hline Lexis & boanon & $\mathrm{ku}$ & do & i & tu & ulaon & adat \\
\hline TS & prosess:material & actor & particle & goal & circumstance:spatial & \\
\hline Lexis & bring & i & & it & to & party & tradional \\
\hline TT & i will ring the cloth to a traditional party \\
\hline LSR & projected clause \\
\hline
\end{tabular}

\subsection{Translating Locution}

\section{Data Analysis}

\subsubsection{Translating Paratactic Locution: Translating Pattern 1 “2}

The result of the translation process of the paratactic locution with pattern 1" 2 based on the SFG and BTA theories indicates that there is a translation equivalence on the level of the lexico-grammatical aspects and on the level of the logico-semantic relation between the ST and TT as shown in the analysis of the following excerpt. 1 saonnari dohonon nami ma ulos pansamot di laenami dohot ibotonami di son,"2passamot angka nauli nadenggan ma on di keluarga ni laengku ibotongku

1now I am saying the ulos pansamot to my brother and sister-in-laws here, "2this pansamot is all the good and the kind for the family of my brother and sister-in-laws

Projecting Clause Translation Process:

saonnari dohonon nami ma ulos pansamot

Table 3 Translating Locution 1

\begin{tabular}{|l|l|l|l|l|l|}
\hline BTL & saonanari & dohonon & nami & ma & ulos pansamot \\
\hline IL & sekarang & mengatakan & saya & particle & ulos pansamot \\
\hline EL & now & am saying & I & particle & ulos pansamot \\
\hline CC & circumstance & process: verbal & sayer & & target \\
\hline T1 & sekarang saya mengatakan ulos pansamot & \\
\hline T2 & now I am saying the ulos pansamot \\
\hline
\end{tabular}

di laemi dohot ibotonami di son 
The Translation Process of Projection from Batak Toba Language into English

Table 4 Translating Locution 2

\begin{tabular}{|l|l|l|l|l|l|l|l|}
\hline BTL & di & lae & mi & dohot & iboto & name & di son \\
\hline IL & kepada & besan & saya & dan & besan & saya & di sini \\
\hline EL & to & brother-in-law & my & dan & sister-in-law & my & here \\
\hline CC & circumstance \\
\hline T1 & kepadan besan saya \\
\hline T2 & to my brother and sister-in-laws here \\
\hline
\end{tabular}

On the level of the lexico-grammatical aspects, the translation process above indicates that it departs from the translation of the word "dohonon" as a verbal process into the phrase "am saying" as an equivalent verbal process, after that to the translation of the word "nami" as a sayer into the word "I" as an equivalent sayer, next to the translation of the phrase "the ulos pansamot" which is maintained to remain the same for it is an untranslatable cultural term, afterwards to the translation of the word "saonnari" as a temporal circumstance into the word "now" as an equivalent temporal circumstance, then to the translation of the phrase "di laemi dohot ibotonami di sini" as a receiver into the phrase "to my brother and sister-in-laws here" as an equivalent receiver, and it arrives at the translation of the phrase "di son" as a spatial circumstance into the phrase "in here" as an equivalent spatial circumstance. On the level of logico-semantic relation, the translation process indicates that the independent clause "saonnari dohonon nami ma ulos pansamot di laemi dohot ibotonami di son" as a projecting clause is translated into the independent clause "now I am saying the ulos pansamot to my brother and sister-in-laws here" as an equivalent projecting clause.

Projected Clause Translation Process:

passamot angka nauli nadenggan ma on

Table 5 Translating Locution 3

\begin{tabular}{|l|l|l|l|l|l|l|}
\hline BTL & passamot & angka & nauli & nadenggan & ma & on \\
\hline IL & pansamot & semua & kebaikan & keindahan & ialah & ini \\
\hline EL & pansamot & every & the good & the kind & is & this \\
\hline CC & ca- & attribute & process: relational & -rrier \\
\hline T1 & \multicolumn{7}{|l|}{ pansamot ini adalah semua kebaikan dan keindahan } \\
\hline T2 & \multicolumn{6}{l}{} \\
\hline
\end{tabular}

di keluarga ni laengku ibotongku

Table 6 Translating Locution 4

\begin{tabular}{|l|l|l|l|l|l|l|l|}
\hline BTL & di & keluarga & ni & lae & ngku & iboto & ngku \\
\hline IL & untuk & keluarga & dari & besan & saya & besan & saya \\
\hline EL & for & family & of & brother-in-law & my & sister-in-law & my \\
\hline CC & circumstance \\
\hline T1 & \multicolumn{7}{|l|}{ untuk keluarga besan besan saya } \\
\hline T2 & \multicolumn{7}{l|}{} \\
\hline
\end{tabular}

On the level of the lexico-grammatical aspects, the translation process above indicates that the translation departs from the translation of the word "ma" as a relational process into the word "is" as an equivalent relational process, after that to the translation of the words "passamot" and "on" as the carrier into the phrase "this passamot" as an equivalent carrier, next to the translation of the phrase "angka nauli nadenggan" as an attribute into the phrase "the good and the kind" as an equivalent attribute, and departs at the translation of the phrase "di keluarga ni laengku ibotongku" as a spatial circumstance into the phrase "for the family of brother and sister-in-laws" as an equivalent spatial circumstance. On the level of logico-semantic relation, the translation process indicates that an independent clause "passamot angka nauli nadenggan ma on di keluarga ni laengku ibotongku" as a projected clause is translated into an independent clause "this pansamot is all the good and the kind for the family of my brother and sister-in-laws" as an equivalent projected clause. 


\subsubsection{Translating Hypotactic Locution: Translating Pattern $\alpha$ “ $\beta$}

The result of the translation process on the hypotactic locution with the pattern $\alpha$ " $\beta$ based on the SFG and BTA theories indicates that there is a translation equivalence on the level of the lexico-grammatical aspects and on the level of the logico-semantic relation between the the ST and TT as analyzed in the following excerpt.

amandok mauliate ma hita tu tuhanta, "Bala nungga dioloi sangkap ni rohamuna $i$ $\alpha$ we say thanks to our god, " $\beta$ since the hope of your hearts is accepted."

Projecting Clause:

mandok mauliate ma hita tu Tuhanta

Table 7 Translating Locution Hypotactic Locution 1

\begin{tabular}{|l|l|l|l|l|l|l|l|}
\hline BTL & mandok & mauliate & ma & hita & tu & tuhan & ta \\
\hline IL & mengucapkan & terimakasih & lah & kita & ke & tuhan & kita \\
\hline EL & say & thanks & & we & to & god & our \\
\hline CC & process: verbal & goal & particle & sayer & target & \\
\hline T1 & kita mengucapkan terimakasih kepada tuhan kita \\
\hline T2 & we say thanks to our god \\
\hline
\end{tabular}

On the level of the clause lexico-grammatical aspects, the translation process above indicates that it departs from the translation of the word "mandok" as a verbal process into the word "say" as a verbal process, then to the translation of the word "hita" as a sayer into the word "we" as an equivalent sayer, after that to the translation of the word "mauliate" as a target and arrives at the translation of the phrase "tu tuhanta" as receiver into the phrase "to our God" as an equivalent receiver. On the level of logico-semantic relation, the translation process indicates that the independent clause "mandok mauliate ma hita tu tuhanta" as a projected clause is translated into the independent clause "we say thanks to our God" as an equivalent projected clause.

Projected Clause:

ala nungga dioloi sangkap ni rohamunai

Table 8 Translating Locution Hypotactic Locution 2

\begin{tabular}{|l|l|l|l|l|l|l|l|}
\hline BTL & ala & nungga & dioloi & sangkap & ni & roha & munai \\
\hline $\mathrm{IL}$ & karena & telah & direstui & rencana & dari & hati & kalian \\
\hline EL & because & has & accepted & plan & of & heart & your \\
\hline CC & conjunction & process: mental & phenomenon \\
\hline T1 & karena rencana hati kalian direstui \\
\hline T2 & \multicolumn{7}{l}{ since the hope of your hearts is accepted } \\
\hline
\end{tabular}

On the level of the lexico-grammatical aspects, the translation process above indicates that it departs from the translation of the phrase "nungga dioloi" as a mental process into the phrase "is accepted" as a mental process, then to the translation of the phrase "sangkap ni roha muna i" as a phenomenon into the phrase "the hope of your heart" as an equivalent phenomenon, and arrive at the translation of the word "ala" as a conjunction into the word "since" as an equivalent conjunction. On the level of logico-semantic relation, the translation process indicates that the dependent clause "ala nungga dioloi sangkap ni rohamunai" as a projected clause is translated into the dependent clause "Since the hope of your hearts is accepted" as an equivalent projected clause.

\subsection{Translating Idea}

\subsubsection{Translating Paratactic Idea: Translating Pattern 1 "2}

The result of the translation process on the paratactic idea with pattern 1 "2 based on the SFG and BTA theories indicates that there is a translation equivalence on the level of the lexico-grammatical aspects and on the level of the logico-semantic relation between the ST and TT as shown in the analysis of the following excerpt.

1 martangiangma hita, "2asa anggiat gabe keluarga namarbahagia nasida

1 let us pray, "2so that they may become a happy family 
Projecting Clause:

martangiang ma hita

Table 9 Translating Paratactic Idea 1

\begin{tabular}{|l|l|l|l|}
\hline BTL & martangiang & ma & hita \\
\hline $\mathrm{IL}$ & berdoa & lah & kita \\
\hline EL & pray & & we \\
\hline CC & process: mental & particle & senser \\
\hline T1 & marilah kita berdoa & \\
\hline T2 & let us pray & \\
\hline
\end{tabular}

On the level of the lexico-grammatical aspects, the translation process above indicates that it begins from the translation of the word "martangiang" as a verbal process into the phrase "let pray" as an equivalent verbal process to the translation of the word "hita" as a senser into the word "us" as an equivalent senser. On the level of logico-semantic relation, the translation process indicates that the independent clause "martangiang ma hita" as a projecting clause is translated into the independent clause "let us pray" as an equivalent projecting clause.

Projected Clause:

asa anggiat gabe keluarga namarbahagia nasida

Table 10 Translating Paratactic Idea 2

\begin{tabular}{|l|l|l|l|l|}
\hline BTL & asa & anggiat gabe & keluarga nanarbahagia & nasida \\
\hline $\mathbb{L}$ L & agar & semoga menjadi & keluarga berbahagia & mereka \\
\hline EL & so & may become & family happy & they \\
\cline { 3 - 5 } CC & conjunction & process: relational & attribute & carrier \\
\hline T1 & agar semoga mereka menjadi keluarga yang berbahagia & \\
\hline T2 & \multicolumn{2}{|l|}{ so that they may become a happy family } & \\
\hline
\end{tabular}

On the level of the lexico-grammatical aspects, the translation process above indicates that it departs from the translation of the phrase "anggiat gabe" as a relational process into the phrase "may become" as a relational process, then to the translation of the word "nasida" as a carrier, afterwards to the translation of the phrase "keluarga namarbahagia" as an attribute into the phrase "a happy family" as an equivalent attribute, and arrives to the translation of the conjunction "asa" into the conjunction "so". On the level of logico-semantic relation, the translation process indicates that the independent clause "asa anggiat gabe keluarga namarbahagia nasida" as a projected clause is translated into the independent clause "so that they may become a happy family." as an equivalent projected clause.

\subsection{Translating Proposition Idea}

\subsubsection{Translating Hypotactic Proposition Idea: Translating Pattern $\alpha$ ' $\beta$}

The result of the translation process on the hypotactic proposition idea with pattern $\alpha$ ' $\beta$ based on the SFG and BTA theories indicate that there is a translation equivalence on the level of the lexico-grammatical aspects and on the level of the logico-semantic relation between the ST and TT as analyzed in the following excerpt.

a martangiang hita tu debata, ' $\beta$ asa dipasaut sude angka nasinangkapan ni rohanta

$\alpha$ let us pray to our god, ' $\beta$ so that all the hope of our heart is blessed

Projecting Clause:

martangiang hita tu Debata (head: $\alpha$ as an independent projecting clause) 
Table 11 Translating Hypotactic Proposition Idea 1

\begin{tabular}{|l|l|l|l|l|l|}
\hline BTL & martangiang & hita & tu & tuhan & ta \\
\hline $\mathrm{IL}$ & berdoa & kita & kepada & tuhan & kita \\
\hline EL & pray & we & to & god & our \\
\hline CC & process: mental & senser & target & \\
\hline T1 & marilah kita berdoa kepada tuhan kita \\
\hline T2 & let us pray to our god \\
\hline
\end{tabular}

On the level of the lexico-grammatical aspects, the translation process above indicates that it departs from the translation of the word "martangiang" as a mental process into the word "pray" as an equivalent mental process, then to the translation of the word "hita" as a senser, and ends at the translation of the phrase "tu tuhanta" as the receiver into the phrase "to our god" as an equivalent receiver. On the level of logico-semantic relation, the translation process indicates that the independent clause "martangiang hita tu debata" as a projecting clause is translated into the independent clause "let us pray to our god" as an equivalent projecting clause.

Projected Clause:

asa dipasaut sude angka nasinangkapan ni rohanta

Table 12 Translating Hypotactic Proposition Idea 2

\begin{tabular}{|c|c|c|c|c|c|c|c|c|}
\hline BTL & asa & dipasaut & sude & angka & nasinangkapan & ni & rohan & ta \\
\hline IL & agar & diberkati & semua & setiap & direncanakan & dari & hati & kita \\
\hline EL & so & blessed & all & every & hope & of & heart & our \\
\hline $\mathrm{CC}$ & conjunction & process:mental & \multicolumn{6}{|c|}{ phenomenon } \\
\hline $\mathrm{T} 1$ & \multicolumn{8}{|c|}{ agar semua yang direncanakan hati kita diberkati oleh tuhan } \\
\hline $\mathrm{T} 2$ & \multicolumn{8}{|c|}{ so that all the hope of our heart is blessed by our god } \\
\hline
\end{tabular}

On the level of the lexico-grammatical aspects, the translation process above indicates that it begins from the translation of the word "dipasaut" as a mental process into the phrase "is blessed" as an equivalent mental process, then to the translation of the phrase "sude angka nasinangkapan ni rohanta" as a target into the phrase "all the hope of our heart" as an equivalent target, and arrive at the translation the conjunction "asa" into an equivalent conjunction "so". On the level of logico-semantic relation, the translation process indicates that the dependent clause "asa dipasaut sude angka nasinangkapan ni rohanta" as a projected clause is translated into the dependent clause "so that all the hope of our heart is blessed" as an equivalent projected clause.

\subsection{Translating Proposal Idea}

\subsubsection{Translating Paratactic Proposal Idea: Translating Pattern 1 '2}

The result of the translation process on the paratactic proposal idea with pattern 1 '2 based on the SFG and BTA theories indicates that there is a translation equivalence on the level of the lexico-grammatical aspects and on the level of the logico-semantic relation between the ST and TT as in the analysis of the following excerpt.

1 pos roha muna, '2sai diramoti ma hamu di parkarejoan muna

1 your heart believes, '2may you be protected at your work

projecting clause:

pos roha muna

Table 13 Translating Paratactic Proposal Idea 1

\begin{tabular}{|l|l|l|l|}
\hline BTL & pos & roha & muna \\
\hline IL & percaya & hati & kalian \\
\hline EL & believes & heart & your \\
\hline CC & process: mental & senser & \\
\hline T1 & percayalah kalian & \\
\hline T2 & your heart believes & \\
\hline
\end{tabular}


On the level of the lexico-grammatical aspects, the translation process above indicates that it begins from the translation of the word "pos" as a mental process into the word "believe" as an equivalent mental process and to the translation of the phrase "roha muna" as a senser into the phrase "your heart" as an equivalent senser. On the level of logico-semantic relation, the translation process indicates that the independent clause "pos roha muna" as the projecting clause is translated into the independent clause "your heart believes" as an equivalent projecting clause.

Projected Clause:

sai diramoti ma hamu di parkarejoan muna

Table 14 Translating Paratactic Proposal Idea 1

\begin{tabular}{|l|l|l|l|l|l|l|l|}
\hline BTL & sai & diramoti & ma & hamu & di & parkarejoan & muna \\
\hline IL & semoga & dilindungi & lah & kalian & di & pekerjaan & kalian \\
\hline EL & may & protected & & you & at & work & your \\
\hline CC & process: mental & particle & phenomenon & circumstance & \\
\hline T1 & semoga kalian dilindungi dalam pekerjaan kalian \\
\hline T2 & \multicolumn{7}{l}{ may you be protected at your work } \\
\hline
\end{tabular}

On the level of the lexico-grammatical aspects, the translation process above indicates that it departs from the translation of the phrase "sai diramoti" as a mental process into the phrase "may...be protected" as a mental process, then to the translation of the word "hamu" as a senser into the word "you" as an equivalent senser, and arrives at the translation di parkarejoan muna" as a spatial circumstance into the phrase "at your work" as an equivalent spatial circumstance. On the level of logico-semantic relation, the translation process indicates that the independent clause "sai diramoti ma hamu di parkarejoan muna" as the projected clause is translated into the equivalent independent clause "may you be protected at your work" as an equivalent projected clause.

\subsection{Findings}

The projection types that Heuristic translation strategy can meaningfully transfer from the Batak Toba Wedding speeches as the ST into English as the TT are as follows:

1. Paratactic locution with the pattern 1 "2 and hypotactic locution with the pattern $\alpha$ " $\beta$

2. Paratactic idea with the pattern 1 "2

3. Hypotactic proposition idea with the pattern $\alpha$ " $\beta$

4. Paratactic propasal idea with the pattern 1 "2

\subsection{Discussion}

The projection patterns in the Batak Toba wedding speeches can be translated into functional equivalent projection patterns into English. The reason why each of the pattern can be meaningfully translated from the ST into equivalent TT because the process of the translation is executed with heuristic translation strategy which departs from the analysis on how the lexico-grammatical aspects creates projection in the ST, from there the process tries the probability of replacing the lexico-grammatical aspect into the TT to realize equivalent projection. To do the validation of the equivalence, the process works on the analysis of the TT to prove its equivalence to the ST. The Analysis is to check the relation between ST and TT per lexico-grammatical aspect and per function of that lexico-grammatical aspect. A match per aspect means that there is a fully functional equivalence between the ST and TT in the extent of a specific pattern of a logical meaning type.

\subsection{Conclusion}

\section{Conclusion And Suggestion}

The way the projection of the ST can be meaningfully translated into TT is by applying heuristic translation approach containing the stages as follows:

Stage 1: analyzing the ST into clauses which are categorized into clause simple and clause complexes in stage; analyzing the ST Projection into locution, idea, proposition idea, and proposal idea in stage 2; executing the Projection transfer by picking up the projection from ST and keeping it in the mind of the translator, then selecting the equivalent lexico-grammatical feature of the TL to replace the lexico-grammatical features of the SL to realize the projection in the TT in stage 3; analyzing the TT Projection to determine locution, idea, proposition idea, and proposal idea in stage 4; and conducting TQA to assess the translation quality. It is to determine the quality of the relation between the ST and TT in stage 5. 


\subsection{Suggestion}

A translation process is suggested to conduct systemic functional grammatical analysis on the execution of the process of translating a ST into the TT. They are suggested to invent specific types of the lexico-grammatical aspect to realize specific logical function in the ST. They are also suggested to do the same analysis on when the logical functions are transferred into the TT. They are suggested to assess the translation quality based on the functional equivalent criteria, i.e. based on a specific lexico-grammatical aspect and a specific logico-semantic relation between the ST of the SL and the TT of the TL.

\section{References}

[1] Sanggam Siahaan, Batak Pragmatics: Communicating Intentions (Singapore: Singapore International Press, 2012).

[2] Bungaran Antonius Simanjuntak, Konflik status dan kekuasaan orang batak toba Jurnal Antropologi Sumatera Universitas Negeri Medan, 1 (2), 2005, 142-154.

[3] T.M. Sihombing, Jambar hata: dongan to ulaon adat (Pematangsiantar: CV. Tulus Jaya, 1989).

[4] W.M. Hutagalung, Pustaha batak: tarombo dohot turiturian ni bangso batak (Pematangsiantar: CV. Tulus Jaya, 1991).

[5] Roger T. Bell, Translation and translating: theory and practice (Longman, London: Newmark, 1991)

[6] Marina Manfredi, Translating text: translation studies and systemic functional linguistics (Bologna: Dupress, 2008)

[7] M.A.K. Halliday, Functional grammar. $2^{\text {nd }}$ edition (London: Edward Arnold, 1994).

[8] J.C. Catford, A linguistic theory of translation (London: Prentice Hall, 1965).

[9] Julianne House, How do we know when a translation is good? (Berlin/New York: Mouton de Gruyter, 2001).

[10] M.R.M. Cowie Shuttleworth, Dictionary of translation studies (Manchester: St. Jerome, 1997).

[11] H.P. Krings, Translation problems and translation strategies of advanced German learners of French, Journal of Interlingual and Intercultural Communication, 1986, 263-275

[12] W. Loescher, Translation performance, translation process and translation strategies (Tuebingen: Guten Narr, 1991).

[13] A.D. Cohen, Strategies in learning and using a second language: 1st edition (London and New York: Longman, 1998).

[14] R. Jaaskelainen, Tapping the process: an explorative study of cognitive and effective factors involved in translating (Joensuu: University of Joensuu Publications in Humanities, 1999).

[15] C. Taylor Torsello, Grammatica e traduzione in G. Cortese Tradurre $i$ linguaggi settoriali (Torino: Edizioni Libreri Cortina, 1996). 